\title{
Beaver Fur and Deer Skin: Teaching Colonial American Literature in Taiwan's Context
}

\author{
Ya-Shu Chen \\ Department of Foreign Languages and Literatures, Chung Hua University, Taiwan
}

Copyright $(2018$ by authors, all rights reserved. Authors agree that this article remains permanently open access under the terms of the Creative Commons Attribution License 4.0 International License

\begin{abstract}
English majors in Taiwan mostly are not familiar with American literature, let along American literature in the colonial times. However, should one compare the colonial history of Taiwan in the Age of Exploration with that of America in the similar era by the Dutch, students are more willing to participate in class discussion, their learning attitude has changed from passive to more active, and the result is therefore more rewarding too. The main reason of such a result lies in that, in my opinion, both colonial histories of Taiwan and US are alike, that is, both were discovered by Europeans in the Age of Exploration, and there are similarities between the colonization processes in Tainan, Taiwan, and several Dutch colonies along the east coast of America. The two colonial powers used trade as a means, exchanging mink and deerskin with native Aborigines respectively and eventually led to the abolition of the two indigenous peoples. This study aims at exploring similarities and differences between Taiwan and US colonial histories through examining their colonization processes in detail. I hope that from such a comparison, putting colonial American literature in the context of colonial Taiwan, American literary history may become more interesting to Taiwan Students.
\end{abstract}

Keywords Colonial Literature, Age of Exploration, Trade, Dutch

\section{How to Teach Colonial American Literature}

It is well known among faculty of English departments that textbooks of history of American literature begin with American colonial literature, including Native American literature. However, the so-called "literature" here, refers actually to "documents," and it is not the literature under a strict definition as commonly known. In view of the fact that the first group of colonists was pioneers who needed to fight for survival, it was almost impossible for them to have the luxury of literary creation. However, at the same time, there were quite a number of invaluable written records that had recorded major events of the pioneers during the $16^{\text {th }}$ and $17^{\text {th }}$ centuries, and these first hand records have become indispensable documents for us to understand the era. Consequently, editors of American literary history textbooks have incorporated these records and documents into the canon, hence the first chapter of American literary history.

Strictly speaking, the aforementioned documents are history, and the major sources for us to understand the colonial times. From the letters and logs of Christopher Columbus (1451-1506), we know how America was discovered [5]. From the logs of Jacques Cartier (1491-1557), we witness, so to speak, the first encounter between the French and Indians [4]. From the description of Samuel de Champlain (1570-1635), we know how the French discovered Quebec. From the depiction of John Smith (1580-1631), we know how England found Virginia, establishing the first English colony-Jamestown there, and also know about the oratory of the Indian King Powhatan [9]. From William Bradford's history, we know how the English managed New England, their most important colony in America [1]. From John Winthrop's diary, we know how Puritans built a Christian community in America [10]. From Adrianne Van Der Donck's account, we know how the Dutch colonized New Amsterdam (modern New York City). Among all these historical documents, the only exceptions, the "real literature" written by a "true poetess," were the works of Anne Bradstreet (1612-1672). Her intimate poems for her family members showed her private feelings, having nothing to do with grand historical context [2].

In the above context, how are we going to teach American literary history? Many English majors in Taiwan are not interested in foreign colonial history. They feel distanced and unrelated to such history. It is not easy, therefore, to teach well this part of literary history, especially in terms of increasing students' interest in it. 
However, through so many trials and errors, I have finally found a method to promote their interest: paralleling Dutch colonial history of northeastern North America with the Dutch colonial history of Taiwan (1624-1662). The Dutch colonial history of Taiwan began in 1624 with the establishment of Zeelandia in Dayuan (Anping). This was also the period roughly coincided with the establishment of the first English colony, Jamestown, VA (1607), and the second its colony, Plymouth Plantation, MA (1620). In fact, ever since Columbus' discovery of America in 1492, the whole world was entering into the period known as the Age of Exploration. In the $16^{\text {th }}$ century, Europeans navigated all over the world (Americas, Asia, and Africa), seeking gold and other valuable resources. From the beginning of the $17^{\text {th }}$ century, Europeans began to set up settlements in Asia and Americas, and they prepared to stay there longer or permanently. England and Holland were the strongest powers yet strictly speaking, Holland should be the strongest nation in the $17^{\text {th }}$ century. The Dutch ran the Dutch West India Company in New Amsterdam, the Dutch East India Company in Jakarta, and they almost monopolized maritime trade. It was not until the second half of the $17^{\text {th }}$ century, England had gradually replaced Holland to become the strongest power in the world.

In order to compare with the Dutch colonial Taiwan, I pay special attention to the Dutch colonial New York. In actuality, many European countries built colonies in America; England, Holland, and France were the major ones. Each country had its own way of colonization. For instance, although some English took interest in trade, most English people preferred to build a holy land free from political interference. With the Dutch, it was another story. They were more into commercial profits, and establishing permanent colonies was not their original plan. However, after the establishment of English settlements, with an influx of settlers, the Dutch forces had been gradually losing out. So the Dutch changed their colonial policy. From 1639, they began to establish colonies, encouraging their people to reside in the colonies permanently, but to no avail. The Dutch were defeated by the English troops eventually, and New Amsterdam became New York, an English colony, in 1664. From the above, we may conclude that the Dutch colonial years in New York were basically from 1609-1664. As for Taiwan, the Dutch's colonization of Taiwan began in 1624, and they were expelled by Zhen Chenggong in 1664 which was closed to the time when the Dutch were defeated by England in North America. Therefore, it is extremely interesting to compare Dutch colonial New York with Dutch colonial Anping. In what follows, I will discuss the two Dutch colonies in the East and the West, particularly the relationship between the colonists and the colonized (Indians and Taiwan aborigines respectively), and the outcomes for both groups of natives. Even though the Dutch had no intention to reside permanently in the said colonies, through mere commerce and trade, nonetheless, both groups of natives were disintegrated. By way of such comparison, students will have a clearer understanding of colonization, and of the meanings and values of American literary history of that period.

\section{Dutch Colonial New York and its Relationship with Indians}

Despite the Dutch discovered the Hudson River in 1609, its major goal was nonetheless commerce. That's why the first commercial outpost, Fort Nassau, was set up as late as 1613. The Dutch merchants not only competed with each other domestically, they were also subject to competition from England, Spain, and France. Therefore, trying to create a monopoly on business, and becoming the exclusive agent of Indian trade, the Dutch formed the Dutch West India Company. They also established a new outpost in Fort Orange in place of Fort Nassau, and meanwhile built a new port, New Amsterdam, in Manhattan. They sold iron axes, textiles, iron goods, glass, weapons, tea, bread, flour, etc. to Indians, and the goods were extremely popular among them. The Dutch, on the other hand, bough local beaver furs from local Indians, and furs were the sole merchandize that Indians sold to whites. However, when an exclusive merchandize was the sole exported product of a society, what, then, would be the impact on that society? Denys Delage [6] analyzed this issue profoundly. Based on Delage's work, I will analyze the impact on Indians after Europeans purchasing large quantities of beaver furs from them. I will also try to clarify, from such an angle, the nature of colonialism.

The Iroquois were the strongest Indian nation residing in Dutch colonial New Netherlands. When trading with other nations, the Dutch had to go through an Iroquois middleman. The Iroquois consisted of six nations, namely, the Mohawk, Onondaga, Oneida, Cayuga, Seneca, and Tuscarora. Starting from 1620, as whites began beaver fur trade with Indians, Indians did not know the prices and market condition of beaver furs, so whites had garnered high profits. However, exactly due to such high profits, traders from such countries as England and France began actively involved in fur trade. Even domestic Dutch merchants, who would not be constrained by the Dutch West India Company, entered the fur trade market, making fur trade a highly competitive free market. Beaver fur prices thus had risen due to the influx of competitive buyers. After a remarkable price hike, thinking fur trade would be profitable, Indians started to hunt beavers massively.

Under such circumstances, Indians' lifestyle had changed dramatically, and their dependency on whites was deepened. Later, when local beavers were almost all killed, for the sake of opening up new fur resources, the Iroquois began to attack the Hurons in northwestern America, launching countless wars, and grabbing beaver fur 
resources. They almost wiped out all the Hurons people who had never experienced such pillage. Afterwards, the Iroquois became a large confederacy, ruling Indians under French and Dutch control. However, through decades of killing, pillage, and famine, coupled with various severe plagues at the time, Indian population of the entire region had reduced greatly, and the whole region became dilapidated. Father Ragueneau, a Catholic Jesuit missionary wrote the following passage when he passed the region, and witnessed such a desolate scene:

A father on, were but the shells of cabins abandoned to the fury of the enemy - those who had dwelt in them having fled into the forest, and condemned themselves to a life which is but perpetual banishment. The Nipissirinien people, who speak the Algonquin tongue, had quite lately been massacred at their lake,--forty leagues in circumference, which formerly I had seen inhabited in almost the entire length of its coast; but which, now. Is nothing but solitude ...So we pursued our way. Alas, that those wretched Iroquois should have caused such desolation in all these regions!

Finally, as beavers were almost extinct, Indians began to hunt other types of animals for their fur so that they would still conduct trade with whites. In order to survive, they even gathered a variety of exotic flowers and fruit, or any other plants that whites preferred to exchange. In addition to causing depletion of natural resources, the relationship between Indians and nature had also changed completely. Delage [6] depicted such transformation in detail:

Ten years later (i.e. 1645), the beaver disappeared from Iroquois. Supplies had to come from ever farther afield, and yet the Amerindians' demand for European products was persistent and kept growing. Tribes therefore diversified their hunting. At Fort Orange, they exchanged deer for cloth worth six or seven florins, but in 1639, when the hunting was good, a deer way traded for a loaf of bread, a knife, or even a pipe. In 1655, the Amerindians were selling turkeys for ten stuivers (ten cents) each. Mercantile relationships were then extended to the gathering of wild plants. The Swedes gave a loaf of bread in exchange for thirty feet of Canadian hemp cord, which was stronger than their own manufactured cord, used for fishing nets. The result of all this was that the Amerindians gradually altered the balance of nature be squandering the wealth of country in order to acquire objects made elsewhere.

From the above discussion we may know that ever since trading with whites. Indians' mode of production, social relationship, and their relationship with nature changed drastically. They would, in the end, trade a deer for a loaf of bread or a knife with whites. This is exactly the most fundamental reason why these tribes would disappear, or be assimilated. In fact, in the $16^{\text {th }}$ century, when Indians and whites had not yet begun to trade, Indians still maintained full dignity and autonomy. They even had the concept of territory sovereignty. Cartier (from Delage:84) narrated his first encounter with an Indian who "indicated the land all around us, as though he wished to say that it all belonged to him, and that we must not erect our cross without his permission." Contrast to a century later when Indians and whites officially launched trade, it is deplorable that the situation of Indians became so unbearable.

\section{Dutch Colonial Taiwan and Dutch-Taiwan Aborigines Relations}

After traveling through many areas, the Dutch came to Taiwan by way of Penghu, establishing Zeelandia in 1624, a year after its establishment of New Amsterdam. China was implementing maritime ban at the time, so it was impossible to set up harbors in China. Therefore, for trade convenience with China (and Japan), Spain set up a harbor in Manila, Holland set up the Dutch East India Company in Anping, directly reporting to the company's headquarters in Jakarta. The Dutch East India Company was a commercial organization, yet the Dutch government gave the company diplomatic power on the ground. Furthermore, if there weren't any leader in the colony, such as the case in Taiwan, the Dutch East India Company actually was given the domination and military power almost equal the sovereignty of a nation. In Taiwan, the major aborigines at the time were Pingpu Tribes with a population of more than hundreds and thousands people. There were few Han people and they mostly settled in Tainan area, trading with aborigines mainly. After the Dutch occupied Anping, the Dutch established Provintia in Zeelandia region, and tried to rule local people. They began the plan of "enlightening" the aborigines by means of establishing schools, churches, infirmaries, etc. Basically, what they did in Anping was similar to that in New Amsterdam, and they also tried to further reduce the dominance of aboriginal leaders. However, their ruling instigated revolt from the aborigines. The Dutch thereupon dispatched troops to put down the rebellion and the aborigines gradually submitted. As a result, the Dutch East India Company convened a local meeting in which they made pacts with the tribes to assure relations of domination, and stipulated that the Dutch dominated regions ranging from Zhanghua to Henchun. In 1642, the Dutch defeated the Spanish. Entire Taiwan fell into their rule.

The Dutch made Anping their trading base after they occupied Taiwan. Aside from getting large quantities of goods from Japan, they also plundered natural resources within Taiwan, and deerskin was the most important natural resource. Before the occupation, merchants from mainland China had already exchanged goods with the aborigines, deerskin being one of the goods. It was exactly the Edo period in Japan after the Dutch came to Taiwan as 
General Tokugawa reigned. He purchased a large quantity of deerskin to make all kinds of military supplies because of his extreme emphasis on military. Consequently, the Dutch began to amass deerskin.

Deer skin was originally a specialty of the aborigines, but the Dutch, in order to increase production, allowed the Chinese to hunt the mountains deer. The Dutch also took tough measures to prevent aboriginal hindrance [11].Under these incentives, indigenous peoples compete with the Han to hunt for deer in Taiwan, resulting in a gradual reduction in deer production.

According to the data of Takashi Nakamura [7][8] and Cao Yonghe [3].In the 1630s, Taiwan exported one hundred thousand pieces of deerskin, and in 1638, the number reached the highest - one hundred fifteen thousand pieces. However, between the 1640 s and 1650 s, deerskin exports decreased, but were still between fifty thousand and one hundred thousand pieces. Between the 1660s and 1670 s, by the late Dutch and the early Ming Zheng, annual deerskin exports were around thirty thousand. By the period of Emperor Kangxi's reign of the Qing dynasty, annual exports dropped to about nine thousand. By the time of Emperor Yongzheng's reign, as local residents began to reclaim plains, no deerskin were left for exporting.

Taiwan aborigines originally had their own agriculture, but the scale, scope were very small. Most of the land was the common ground, belonging to the common property, The land was basically grass and forest which were the deer farms at that time. The Dutch encouraged the Han people to move into planting rice and began to occupy and reclaim the communes. The deer were only being hunted in large numbers, while others fled to the mountains. Aboriginal hunting objects began to disappear. Part of the aborigines migrated into the mountains while those left on the plains could no longer rely on hunting for a living, so they began to learn to grow rice with the Han Chinese, and they also have slowly assimilated into Chinese at the same time. According to the statistics, most of the plains near Tainan in the 1640s had been reclaimed, while the remaining number of deer was very small. Aboriginal people's dependence on the Han Chinese, because of the loss of the past mode of production, was also getting higher and higher. Cao Yonghe [3] described as follows:

Among the land neared the plains, deer habitats had been extinct, so the natives went into farming. Many of the original deer farms owned by the natives had changed into a pastoral. However, the natives of plains, first contacted with the Han Chinese, had slowly assimilated, so their economic life had gradually separated from the original self-sufficiency, to that of the dependence on the Han Chinese. There previous transactions with the Chinese such as deerskin, antlers, deer, velvet, etc., would be sufficient for their desires. However, due to the reduction or extinction of deer, the economic money no longer existed. The only remaining property of value to the outside world was the land.

\section{The Meaning and Inspiration for Teaching}

Through this comparison of the two colonial events, I have gained two valuable experiences. One is that I have a deeper and more refined understanding of the "relationship between colonialism and the indigenous peoples." The second is that my teaching of colonial history have a different experience. I will explain separately as follows:

First, on the issue of colonialism and aboriginal relations: In the past, colonial research on white people against indigenous peoples rarely came from a comparative perspective. Therefore, in these studies, such as Delage's, though we also saw the aboriginal people gradually disappear after the white invasion, the gradual disappearance descriptions were often very complex and heterogeneous, and it seems difficult to draw from them a more "commonplace" theoretical perspective. However, from the comparative perspective of this study, we can clearly see that invaders in the aboriginal areas caused the aborigines to disappear. In fact, the methods used were the same, that is, trade. We found that in the course of trade, aboriginal people lost step by step what they originally owned, and finally, either death or naturalization. Certainly, this is only the result of the comparison between the two societies. A more accurate theoretical view may require more comparative cases to be put forward. It is hoped that this study, as an attempt to compare colonial history, can lead to more relevant researches and give us a more macroscopic understanding of "colonialism and aboriginal relations."

Why is trade so destructive? First of all, through trade, whites exchange the necessities of life, such as breads, knives, pipes, etc., with indigenous peoples for valuable natural resources such as mink and deerskin. Because of the good prices (at least initially), many Aboriginal people have given up on their original jobs, such as farming and changing into hunting and trading. Thus, trade is not just a trade; it changes the mode of production of indigenous societies. Gradually, fewer and fewer people were engaged in agricultural production or other arts and crafts, and therefore relied more on white necessities. Once this dependency had been established, indigenous peoples could only survive through trade and hunting and rely more and more on white people. In the end, the most precious natural resources were gone, so they had no other alternatives but to trade exotic fruits and flowers. However, when all the natural and precious things disappeared, the indigenous people not only lost their nature, but also lost their past mode of production and social relations. At this time, naturalization was the only way for them.

Under this understanding, when we read the various documents and records at that time, our understanding will be more enforced. For example, why was the word 
"sovereignty" in Cartier's works slowly disappearing in documents of the $17^{\text {th }}$ century? Why were Father Ragueneau's depictions of the Dutch and French colonies so bleak? His words are so rich in emotion, allowing us to reflect upon deeply the violence and oppression of American colonization process, and also help us understand more why history of American literature will start from the colonial period.

Second, the teaching of colonial history: If the comparative perspective is very important, then we should actively localize the teaching of foreign literary history, and incorporate the colonial history of those corresponding to foreign colonial history into the teaching content. Let students grasp the meaning and connotation of colonialism through historical comparison. More importantly, not only must the reading materials be added to the elements of the place, but cultural relics in the history of the place should also be included in order to enhance teaching effectiveness. In this case, the Dutch Colonial Museum in Anping, Tainan --Fort Zeelandia Museum, retains many of the colonial artifacts, pictures, models, etc., that are helpful in understanding 17the century Taiwan colonial history. Therefore, if these historical relics are included in class discussion, static teaching of the literary history can be transformed into a dynamic, visual and material classroom interaction so as to enhance students' interest in learning.

I personally make extensive use of these pictures or artifacts in the teaching process, so my students' understanding of this history is vivid. Originally, students were almost completely indifferent to those distant, foreign colonial histories. However, when they saw these pictures and saw the appearances of schools, medical clinics and churches of that era, their interest in learning was significantly enhanced. In other passages of the course, many students even were phubbing or talking to each other, but they were able to concentrate and even participate in the discussions while viewing these specific pictures or artifacts. What is most impressive is that students finally have a holistic understanding of the issue of the disappearance of colonialism and aboriginal people. Of course, these are just on-site observations. What kind of effect does this kind of teaching have, and what kind of more elaborate designs may lead to more accurate answers?
These are also the goals of the next phase of this study. However, as a tentative start, if we can draw more people together to discuss this topic, not only more comparative perspectives but also theoretical perspectives can be improved, so more exciting teaching methods can be devised. This is what this paper is most anticipated.

\section{REFERENCES}

[1] Bradford, W., 2002. "Of Plymouth Plantation," in Carla Mulford (ed.) Early American Writings. Oxford: Oxford U Press.

[2] Bradstreet, A., 2002. "The Four Ages of Man," "Several Poems," in Carla Mulford (ed.) Early American Writings. Oxford U Press.

[3] Cao Yonghe, 2011, Research on Modern Taiwan Deerskin Trade: Young Cao Yonghe's Academic Set Sail. P. 112; 220. Taipei: Yuanliu.

[4] Cartier, J., 2002. 'The First Relation,' in Carla Mulford (ed.) Early American Writings. Oxford: Oxford U Press.

[5] Columbus, C., 2002. "First Voyage to America, 1492-92" in Carla Mulford (ed.) Early American Writings. Oxford: Oxford U Press.

[6] Delage, D., 1993. Translated by Jane Brierley, Bitter Feast: Amerindians and Europeans in Northeastern North America, 1600-64. P. 155. Vancouver: UBC Press.

[7] Nakamura, Takashi, 1997, History of Dutch Taiwan. Volume 1: Overview and Industry. Taipei: The National Library.

[8] Nakamura, Takashi, 2002, History of Dutch Taiwan. Volume 2: Society and Culture, Taipei: The National Library.

[9] Smith, J., 2002. "Proceedings of the English Colonies in Virginia," in Carla Mulford (ed.) Early American Writings. Oxford: Oxford U Press.

[10] Winthrop, J., 2002. "A Model of Christian Charity," in Carla Mulford (ed.) Early American Writings. Oxford: Oxford U Press.

[11] Yang, Yanjie, 2000, History of Dutch Colonial Taiwan, Taipei: Lianjing. 